\title{
Article \\ The Historical and Cultural Value of RC Constructions and the Main Critical Issues for Rehabilitation
}

\author{
Marco Vona *(i) and Benedetto Manganelli (D) \\ School of Engineering, University of Basilicata, 85100 Potenza, Italy; benedetto.manganelli@unibas.it \\ * Correspondence: marco.vona@unibas.it
}

check for

updates

Citation: Vona, M.; Manganelli, B. The Historical and Cultural Value of RC Constructions and the Main Critical Issues for Rehabilitation.

Infrastructures 2022, 7, 35.

https: / / doi.org/10.3390/

infrastructures7030035

Academic Editor:

Francesca Sciarretta

Received: 21 February 2022

Accepted: 4 March 2022

Published: 6 March 2022

Publisher's Note: MDPI stays neutral with regard to jurisdictional claims in published maps and institutional affiliations.

Copyright: (C) 2022 by the authors. Licensee MDPI, Basel, Switzerland. This article is an open access article distributed under the terms and conditions of the Creative Commons Attribution (CC BY) license (https:// creativecommons.org/licenses/by/ $4.0 /)$.

\begin{abstract}
In recent years, the preservation strategies of cultural heritage have become an element of considerable importance. Unfortunately, research has often been conducted in an excessively mono-sectoral or disaggregated manner. Moreover, there is a significant number of reinforce concrete (RC) buildings and engineering works that are of historical interest and play a key role during the earthquakes. An urban center, its historical structures and infrastructures or single buildings, if well managed, preserved, protected, recovered and enhanced can represent an excellent source of income and induce a considerable economic development in the neighboring areas. On the other hand, a lack of value appreciation and/or incorrect management represent a significant economic loss in the long-term, but an immediate loss after earthquakes. In this work, the historical and cultural value of these RC structures and infrastructures is discussed and the main critical issues are identified, outlining the fundamental requirements for conservation.
\end{abstract}

Keywords: RC buildings and engineering works; seismic risk mitigation; community resilience

\section{Introduction}

The preservation strategies of cultural heritage have becomean element of considerable importance. From a research point of view, this topic is decidedly multidisciplinary and involves: History and Architecture, Art, Tourism, Urban Planning, use and reuse of the territory, buildings and civil engineering works, etc.

The focus of current paper is the recovery, enhancement and choice of the best management strategies of historical, artistic and architectural heritage.

Both the monumental and cultural buildings (single or large-scale urban) as well as structures and infrastructures are considered. They can be publicly and privately owned and can be severely degraded and underused, if not, in many cases, unused.

Unfortunately, research has often been conducted in an excessively mono-sectoral or disaggregated manner. The result of these studies and their subsequent application is often negative in terms of actual conservation capacity.

In Italy, there is a significant number of buildings and infrastructures that are of historical interest. Based on their fundamental strategic role and past events and importance, they played a key role during the last earthquakes and have contributed towards aggravating the vulnerability inside or outside the historic centers [1,2] of the urban areas, and zeroing out community resilience [3].

After the last earthquakes, there has been significant damage to monumental and historical buildings (e.g., earthquakes in central Italy [4]) and the consequential losses and impacts on the cultural aspects have often resulted in negative and irreversible effects (for example, on tourism).

On the other hand, the damage to residential buildings and infrastructures was so substantial as to cause immediate and irreversible losses in value (high and unsustainable repair/reconstruction costs). In the medium/long term, the global effect in terms of environmental degradation on the communities has also involved less damaged buildings. 
An urban center, its historical structures and infrastructures or single buildings, if well managed, preserved, protected, recovered and enhanced can represent an excellent source of income and induce a considerable economic development in the neighboring areas.

On the other hand, lack of and/or incorrect management represent a significant economic loss in the long-term, but an immediate loss after earthquakes. For these reasons and for a significant improvement in the current practices of recovery, the use and reuse of monumental and historical assets is needed.

Since its beginnings in the late 1800s and early 1900s, the application of reinforced concrete $(\mathrm{RC})$ has represented a real revolution in the world of buildings and civil engineering works. The flexibility provided bythese buildings and civil engineering works was the basis for the works that at the time were to be considered new and daring. This is why, in recent years, more and more RC structures and infrastructures (buildings and civil engineering works) have been classified as historical constructions.

In this work, the historical and cultural value of these RC structures and infrastructures is discussed and the main critical issues are identified, outlining the fundamental requirements for conservation.

This paper proposes an excursus to highlight and explain how 20th-century RC constructions could be considered historical/monumental and, consequently, worthy of an appropriate conservation. In this way, the paper does not want to be a new proposal and consequently cannot be compared with proposals presented in the literature. It should be emphasized that the retrofit of existing RC constructions is a very complex topic. Moreover, the problems can be greatly amplified for historical RC constructions. In this way, it is to be noted that, regardinghistorical masonry buildings, there are a significant number of studies, guideline, and codes. Consequently, the retrofitting strategies, materials, and techniques that are currently used are widely and clearly defined. On the contrary, the rehabilitation and retrofitting of historic $\mathrm{RC}$ constructions are much more recent themes and for which awareness is not yet widespread. These topics comprise all those matters that are usually involved in the conservation of the monumental and cultural heritage and where the greater difficulties lie in the complexity of the interventions that are to be carried out on a regular basis and where the construction remains operational and with significant importance classes, III and IV for EC8 code [5]. Future recommendations must consider that no "balancing act" or "trade-off" is possible for structural safety. To this end, lastly, the paper does not report a case study. New proposals or comparisons should not be necessary: structural safety is a fundamental requirement, which should not be violated.

\section{RC Buildings and Civil Engineering Works: Cultural and Historical Value}

First of all, it must be emphasized that the current definition of historical and cultural heritage includes (or should include) new types of structures, built mainly in the twentieth century. They represent the very strong evolution that the new construction techniques have brought from the 19th century. As a matter of fact, in the last few years, the study of RC constructions (since the 19th century) has assumed the typical characteristics of the conservation of cultural heritage, specifically understood as principles, methodology and conservation techniques.

These constructions are recognized as historical heritage sites of their construction periods and in particular, the value they bring to the strong innovation that RC buildings and civil engineering works have introduced. The first and most relevant applications were evidentlyon big works, bridges in particular (Billington, 1983), using, since the early 1900s, concrete prestressing methods.

The first applications were followed by great excitement and a considerable impulse to construction techniques as well asto the study and development of new models and methods of design and construction. These applications gave structural engineering an actual and new form of art [6]. The construction of great RC buildings and civil engineering works has had a very strong impulse thanks to the inventions of Eugène Freyssinet [7-9] and the genius of designers/builders, such as Robert Maillart [9]. In demonstrating the 
strong impulse for community development and modernization, some RC applications have been incredible and perhaps even unrepeatable.

In Italy, there were some great precursors in the use of this new technology and some relevant applications, ranging from long span bridges to the reconstruction following the Messina earthquake (1908) to the reconstruction (sensational at the time) of the structure of the bell tower in Piazza San Marco in Venice (Figure 1) [10]. In the second half of the twentieth century, the great potential of RC constructions strongly emerged, giving impetus to the economic recovery and the post-Second World War structural and infrastructural reconstruction of many European countries.

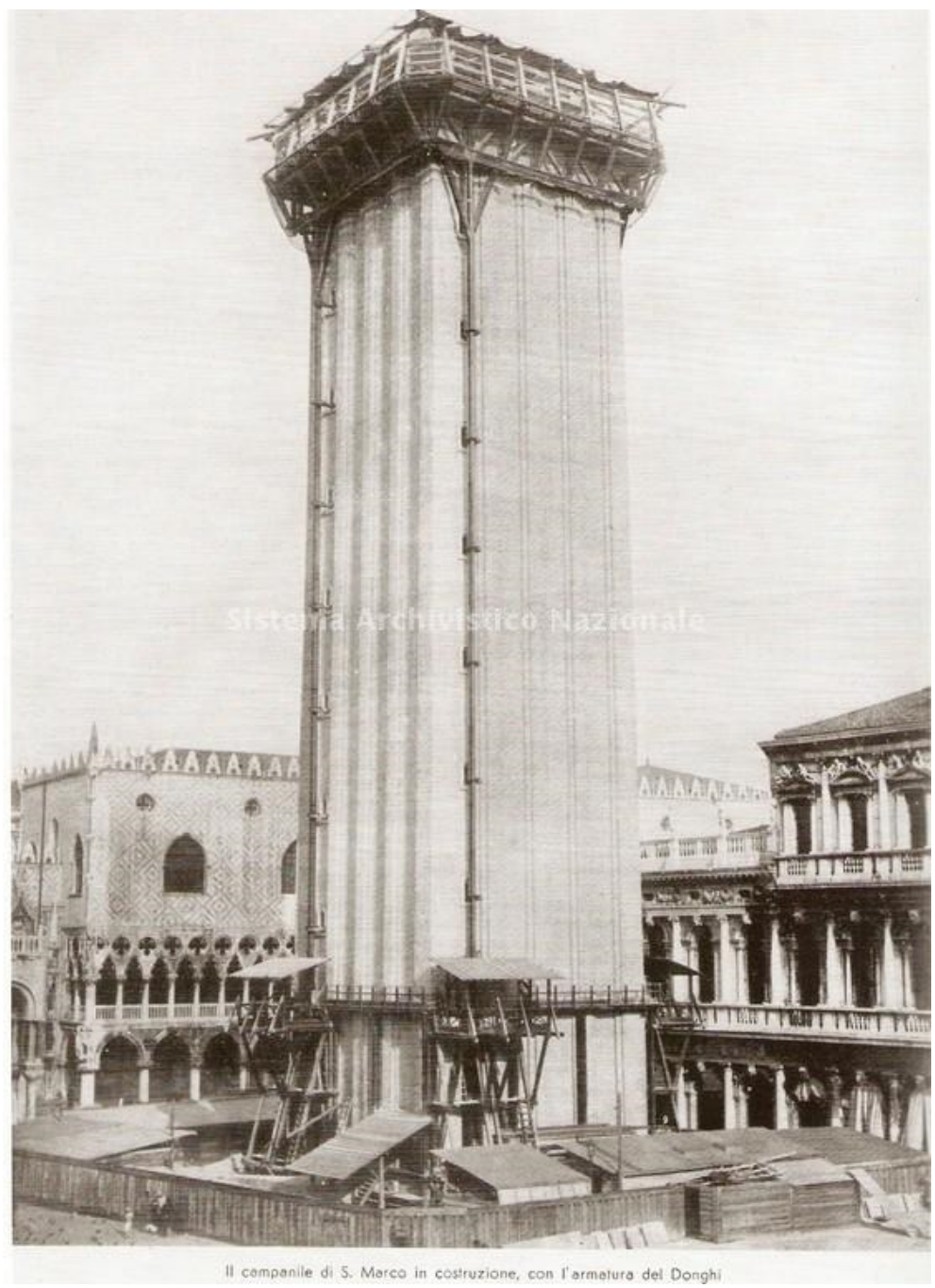

Figure 1. Reconstruction of the San Marco bell tower, Venice (http:/ / san.beniculturali.it/web/san/dettagliooggetto-digitale?pid=san.dl.SAN:IMG-00429727, Sistema Archivistico Nazionale, December 2021).

At that time, the Italian (butnot only) regulations were rather poor and lacking in details. In this regard, several post-earthquake reconstruction codes and standards of the early twentieth century can be considered. In Italy, the first code was the Royal Decree no. 2229 of 1939 [11]. Professional practice and applications were based on books and experimental applications.

On these bases, in Italy big infrastructures were built (bridges and overpasses) as well as structures for public, civil and industrial use where several designers contributed, such as Pier Luigi Nervi, Arturo Danusso, Riccardo Morandi, SilvanoZorzi, Sergio Musmeci, Sergio Lenci, Marcello D'Olivo and many others. In actual fact, the great and major diffusion of the RC constructions took place starting from the second half of the 1950s, when, due to 
the great economic development (in Italy and Europe), a significant demand for services (structures and infrastructures) and new housing was becoming stronger. The study of this period is widely reported in several works, for example, in [12-16].

The RC constructions lent themselveswell to the new development. Large housing volumes and large infrastructures could be built in a short time and at relatively low costs. However, the need to carry out large works and/or large volumes (of concrete) forced a strong acceleration towards the concrete production processes based on competition between producers. Consequently, starting from the lower mechanical characteristics generally required by the regulations in force at the time, many of the concretes are characterized by a strong variability $[17,18]$.

At that time, and for many years to follow, the capacity and durability of the RC buildings and civil engineering works have been overestimated inconsistently with the methods of design, construction, and (above all) maintenance [19,20]. Moreover, the (initial) lifecycle is often not consistent with conceptual design procedures and construction errors that are typical of the age, as is clearly highlighted in the comparison with current practices and regulations. For RC constructions, the current criticalities on a large territorial and economic scale also derive from the overestimation of the capabilities and performance in the long term.

Furthermore, the overestimation of the durability and capacities has often led to an incorrect and lack of maintenance, further aggravated by the architectural choice of "exposed concrete", also used in particularly aggressive locations and environments [21].

The corrosion of the reinforcement is one of the main problems of the existing RC buildings and civil engineering works, especially affecting their durability, strength and ductility. The damage caused by corrosion (with a volume of 2-6 times that of the initial values) implies the significant stress and weakness of the concrete. Globally, the stiffness, strength and deformation capacities of RC buildings and civil engineering works are significantly compromised. A significant number of studies are currently available, and it is to be highlighted that the corrosion damage and consequences are difficult to treat and, in any case, implicate very expensive interventions.

As a consequence, the historical-artistic-cultural RC buildings and civil engineering works, built between the 1950s and 1970s, currently show a significant lack in design, as well as damage and functional deficiencies that are difficult to remove and often cause terrible and complete collapses even under live loading only. This critical issue is clearly amplified in earthquake prone regions and by the considerable number of buildings and civil engineering works. For example, in Figure 2a, the synthetic representation of the distribution of the age of residential buildings and civil engineering works is reported (ISTAT, https:/ / www.istat.it, accessed on December 2021).

The rehabilitation of historic constructions is also an important issue for the E.U. Particular attention is needed and currently recognized to preserve historical values. Nevertheless, the current classification of historical constructions for reinforced concrete is not yet exhaustive.

On a global level, the lack of criteria for the recognition and protection of historical values for RC constructions plays a key role. Consequently, the lack of specific methodological approaches is evident. Several studies have been conducted to discuss the significance and attribution of historical values and cultural heritage [22,23].

Furthermore, if several studies are available that discuss how to achieve the E.U. climate targets, for example [24,25], for structural restoration, a significant amountstudies are still needed, but firstly it must be understood that no "balancing act" or "trade-off" is possible for structural safety. In this sense, several case studies have been presented [26-30].

In particular, several studies have been carried out to investigate about the performance of bridges. Nevertheless, in Italy, these studies generally do not consider the historical issue [31-33]. In fact, a significant incentive to conduct these studies has been given by the Polcevera bridge collapse (Genoa, Italy) on 14 August 2018 [34] and the 
intervention strategies necessary for the retrofit and management on a large number of constructions [35].

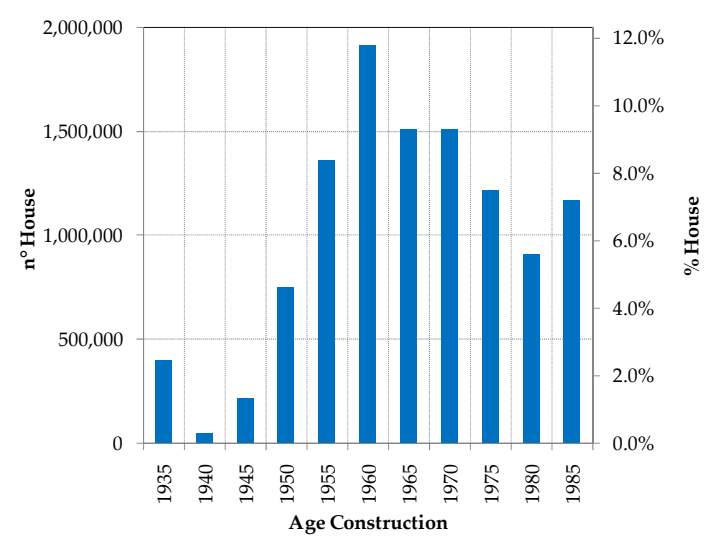

(a)

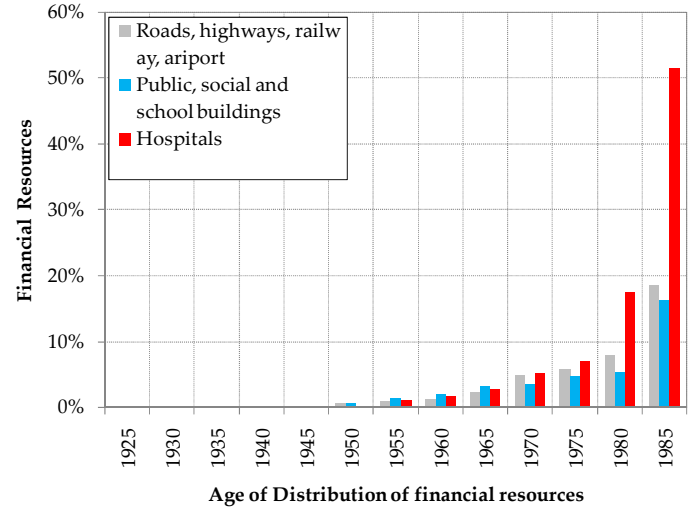

(b)

Figure 2. Residential buildings and main civil engineering works, according to the last Italian census involving both houses and construction: (a) distribution byage of houses built; (b) distribution of financial resources for engineering works totally or partially statefunded (source: www.istat.it). The age classes (construction or distribution of financial resources) considered are commonly used in socio-economic surveys and in post-earthquake surveys.

The recovery and conservation of these RC buildings and civil engineering works are often threatened by the lack of a correct approach to the problem. To solve the problem, several matters must be addressed at the same time. Multiple, overlapping and contrasting factors that influence the choice of the type of intervention and intervention works must be considered.

On the other hand, in introducing the main topic of this work, it is important to investigate the design, construction and maintenance methods of the last century. They identify the primary elements in order to define a correct intervention methodology for the assessment and restoration of RC buildings and civil engineering works.

\section{Methodological Approach for Retrofitting}

Cultural heritage, in terms of the building stock, architectural and urban aspects and historical values of the twentieth century, is often in the great buildings and civil engineering works of the designers of the time. Currently, these constructions (mostly in RC) are considered, by all intents and purposes, as cultural heritage, and therefore to be preserved.

Recent earthquakes have highlighted the extreme vulnerability of these constructions, which have often suffered irreversible damage. In other cases (particularly for some bridges), it was instead the inadequate maintenance that generated damage and irreversible or high losses [36,37].

Consequently, for structures or infrastructures thathave public and strategic functions, the conservation and management of their historical heritage overlaps with the need to guarantee the required level of safety.

This issue often increase the necessary economic resources required and is in contrast with the limited financial resources often available [38-40]. In addition, the current retrofit strategies for RC buildings and civil engineering works are often considered contrary to the common conservation principles for cultural heritage. In fact, the application of the basic concepts commonly used for cultural heritage [41] generally entail that the buildings and civil engineering works be preserved as much as possible.

Nevertheless, the common and consolidated experience on historical buildings (particularly masonry buildings) shows that the changes made over time are themselves a representation of the significance of the buildings in the various historical contexts. 
Therefore, the problem could be addressed in a non-ideological way, by considering the retrofit as a result of the analysis and evaluation procedures followed for the quantification of the direct and indirect economic effects of the intervention to be implemented.

In particular, taking into account the economic and social costs of a possible collapse as well as the need to use the investigated buildings and civil engineering works according to modern standards, the interventions must first and foremost be oriented towards safeguarding people's lives. Moreover, the conservation restrictions (for example those imposed by the Superintendence in Italy) could represent an actual obstacle against preservation. A rigid approach to the protection of a cultural heritage could determine a lack of the necessary safety requirements. On the other hand, the buildings and civil engineering works could be used in a non-economically sustainable way, and this can ultimately lead to the abandonment of a building or its inactivity. A highly multidisciplinary approach is required, where structural safety plays a key role. The approach must be based on the integration of all the requirements. An optimal retrofit strategy must be considered for the use and reuse of RC buildings and civil engineering works, following well-known multi-criteria schemes [42,43] and resilience concepts [44].

According to the latest procedures and performance requisites, the following main issues must be considered:

- Social sustainability (safety of the buildings and civil engineering works).

- Economic sustainability (enhancement of the buildings and civil engineering works).

- Environmental sustainability (for example, the energy performance of the buildings).

With regards to the existing RC buildings and civil engineering works, the following critical points must be highlighted:

1. Construction technologies, design standards and methodologies, procedures, design loads, construction details, design working life and durability, materials, etc., which are noticeably different from the forecasts of current codes.

2. Durability (without significant loss of utility) and maintenance programs are inconsistent with the requirements of current regulations. As a consequence, a high level of degradation is usually detectable.

3. Buildings and civil engineering works without required performances for public safety. 4. Lack of methods and reliable procedures for decision making.

As regards point 1 , an analysis of the codes is necessary. For reinforced concrete constructions, the most recent codes and standards require specific investigation and evaluation procedures.

As far as major road works (mainly bridges) are concerned, the codes (for example, the Italian code) do not contain specific elements. The Italian code reports some elements, while other details are reported in recent and specific guidelines. In any case, these references do not contain specific procedures for a historical heritage.

At present, the code's procedures for existing RC buildings and civil engineering works are centered on a specific survey based on the levels of knowledge. Field investigations and in situ and/or laboratory evaluations and tests are needed.

The focus of the investigations is the identification of possible criticisms that can give rise to unsatisfactory conditions (static and dynamic). They must be described in order to be able to make an initial and rapid assessment.

The preliminary identification of the criticisms and their causes (for example, weaknesses and deficiencies, and existing damage) are useful to address the investigationsbetter. The knowledge process is based on the renowned information:

- Original procedures for design;

- Reconstruction of the history, the state of use and maintenance, as well as of the seismic events and/or other events of particular importance that affected the structure;

- Presence of any conditions of damage and/or degradation and their evolution, particularly for corrosion. 
The original design philosophy is extremely important to evaluate itsdifferences from the current regulations and consequently the true level of construction safety. The loads and actions reported by modern codes are generally far greater than those adopted for the design of the buildings and civil engineering works. Furthermore, the requirements for materials and details are noticeably different.

For example, current codes provide for specific exposure conditions. These strongly affect the characteristics of the materials and details. In existing RC constructions, these requirements are substantially absent and/or neglected. The negative effects on conservation and degradation are very strong.

The mechanical characteristics of the concretes (designed and constructed up to the 1970s) are quite different from those of current concretes. The available experimental results $[45,46]$ have highlighted the existence of a significant variability of the characteristics of the concrete within a single structure and a single element [47]. Some studies are available on the concrete used during the 20th century [17,48-50], but significant investigations are still needed.

The strengths and mechanical characteristics of concrete have significant consequences on the safety levels of the structures and play an important role in corrosion, which represents one of the most widespread and serious problems of degradation. The above issues are often neglected or underestimated in the evaluation and retrofit design process.

The structural effects of corrosion are significant and renowned. They affect the strength of the reinforcement and lead to a significant reduction in capacity [51-57].

Unfortunately, only a limited number of studies are available with regards to the cyclic behavior of corroded elements, such as [58-60], and their influence on the global safety of constructions. As a matter of fact, the treatment of corrosion is a very complex problem: often the structural elements are not immediately and easily visible and inspectable, irremediably delaying the evaluation of the problem and the possible solutions. The reduction inperformance affects the residual design working life.

However, the collapse could also be considered as a complete or partial "out-of-service" of the buildings. In some cases, a partial operation does not guarantee the satisfaction of the functioning of the structure and, all the more, may not guarantee an adequate level of safety. Degradation effects are very evident in road structures, but are also relevant in buildings with a poor maintenance. Furthermore, regardless of their current state, the use of existing RC buildings and civil engineering works cannot come about without an actual safety assessment and consequent retrofit. It must guarantee the preservation of the historical asset, but, above all, people's safety.

In this way, it must be highlighted that many of the RC buildings and engineering works of historical interest or thatcould be of historical interest are still used in public functions, with large crowds of people and with high levels of use.

For example, bridges are still in use and play a key role. Many RC buildings often have shapes and dimensions that foresee an intensive use and an exclusively public function, such as hospitals, which are often very interesting elements thatperform a fundamental social function, even more relevant in emergency management.

Therefore, the level of structural safety is a priority. It must be considered fundamental for any retrofitting and use/reuse of existing buildings.

\section{Statement of Objectives}

The management and enhancement of real estate assets, including those of historical interest, owned by public administrations, are central and highly topical issues. The capital strategies implemented by the public administrations have changed. From a type of management that was first oriented towards conservation, which we can define as static, the form of management has now become dynamic, as real estate is considered an opportunity and therefore a possible source of income. The existing heritage, including post-war modernist buildings, is an important energy, cultural, social and architectural resource. There are several feasible reuse strategies that also differ according to the state of use of the build- 
ing. In buildings still in use, the renovation is intended as a modernization intervention aimed at achieving a technical-functional upgrade according to current standards.

For buildings that have not been in use for a long time, abandoned and in a state of total abandonment, or still in use but close to this condition, the renovation is intended as a revitalization process.

This process can be characterized as conversion, re-design of spaces, modification of the original structural system by increasing or reducing existing volumes and creating new spaces within and between existing volumes.

All the aforementioned renewal strategies are not to be understood as mutually exclusive, but can be simultaneously implemented, depending on the project objectives and the needs of the community. In these strategies, recycling is understood not only as the recycling of building materials, but also the recycling of the design, of the structural form, of the historical and traditional building typologies, which can be transposed into the current context, in a modern key.

The lack or limited availability of financial resources, the absence of effective mitigation strategies and reuse, are criticisms thatincrease losses.

The correct allocation and the spatial-temporal distribution of resources (public and private) should first of all be based on studies to maximize the effects of the resources.

The careful planning of maintenance interventions not only brings benefits for owners, such as improved performance of the building system, greater income capacity, increase in the market value of the property, but also benefits for the entire community [61].

The convenience of maintenance is a function of the market value of the building, which, in turn, depends on factors that affect the urban rent [62], and thatare difficult to quantify exactly. On the one hand, changes in the social, urban and economic context and, on the other hand, continuous technological progress with consequent changed functional and aesthetic needs, are responsible for the high uncertainty in forecasting the potential future values of properties.

Moreover, the convenience of maintenance is also a function of its cost. The latter should not be considered in absolute value, but in relation to the direct benefits in terms of greater utility, and indirect in terms of the increase in the value of the asset. The maintenance intervention will be the more effective the closer the time interval between two successive interventions (known as periodicity) is close to the optimal one. This optimal periodicity is a function of the specific intrinsic characteristics, for example properties of the material, and of the conditions of use of the specific component. In reality, however, the absence of an efficient maintenance management model means that maintenance interventions are usually carried out too late. This delay causes an increase in the costs necessary for repairs in the long term and a reduction in the useful life of the parts of the building components [63].

There is a very strong relationship between depreciation and maintenance. Wellmaintained properties show much lower depreciation rates than properties that have been subjected to poor maintenance [64].

The dissemination and profound knowledge of the socio-economic and financial benefits resulting from preventive interventions (integrating different needs: structural, functional, energetic and conservation of the buildings and engineering works) can also have the beneficial effect of inducing and favoring both public and private capital investment [65].

Highly vulnerable buildings and civil engineering works are increasingly threatened by natural and anthropic-induced risks. However, they play a key role in current communities. The expected performance level and potential losses must be assessed in a multidisciplinary way. The governance of risk must be based on a method that measures the performance and protection level of a cultural heritage.

The levels of performance depend on the external actions and load distribution that are consistent with the retrofit intervention strategies. These actions depend on the design working life, and therefore on the requirements of serviceability, strength and stability. 
For existing RC buildings and civil engineering works, these requirements could entail a significant unforeseen and recurring maintenance based on their public functions and subsequent limit states. A proper hazard level designation must be defined taking into consideration the site hazard and the seismic action linked to the age of construction, the residual working life, and the evaluated post retrofit working life.

The intervention strategies and subsequent procedures must be based on activities and methodologies starting from an accurate characterization of the constructions in reinforced concrete, using innovative techniques of a high qualitative/quantitative level for the survey $[66,67]$.

In this context, it should be noted that the current codes define a working life of at least 100 years for buildings and engineering works of significant importance. However, the action, loads, and seismic actions depend on the correct definition of the considered time (or real working life).

Effective and reliable performance evaluation plays a key role and cannot be postponed further. Regardless of the possible historical interest, for buildings and engineering works with a public function (hospitals, schools, barracks, bridges, etc.), the operational limit state should always be considered, adopting the strongest possible earthquake as the seismic event for the design. On the one hand, this assessment could be decidedly burdensome and unsustainable for many of the existing buildings, whereas on the other hand, it could even be underestimated compared to the actual expected earthquake and its probability of occurrence in the working life. To this end, a correct definition of the hazard must take into account the actual site characteristics for the seismic assessment and the residual working life [68,69]. Maybe, a deterministic approach for seismic action evaluation is the optimal strategy.

Lastly, intervention strategies should be innovative in the sense of allowing quick and efficient interventions, aimed at specific objectives for the protection and conservation of the historical heritage. Approaches, materials and methodologies that are able to merge all the deliberated aspects must be taken into consideration. To this end, economic models are undoubtedly necessary for the cost-benefit analysis of retrofit interventions.

Operational intervention strategies should come about via the use of techniques that make it possible to respond, on the one hand, to the needs of use of the buildings, and on the other hand, to maximize the economic effects of the intervention as much as possible, preserving the original construction characteristics (for example, considering reversible or external techniques).

The assessment of the economic sustainability must be based on the quantitative and comparative evaluation between the lifecycle (based on the working life) and the economic benefits, among which are the overlooked and possible direct economic losses that derive from the non-intervention.

Among the direct costs as well as the social costs resulting from the casualties, if the retrofit of the building and engineering works is possible, the costs deriving from periods of non-use must be considered as opposed to the costs for a preventive retrofit. The latter also involves the non-cost (therefore the benefit) that indirectly derives from the loss of community activities also understood as a set of social, cultural and economic activities, or those connected to the time needed for the global recovery.

Based on the above statement, the retrofit design must be based on:

1. Seismic and gravity loads structural assessment;

2. Comparison of different retrofit strategies;

3. Selection of an optimal retrofit strategy based on the results of the assessment.

Decisions for the retrofit strategy must be taken based on the need (strong point of the rehabilitation project) to minimize the impact on the use of the constructions.

Retrofit strategies were considered with their different advantages and shortcomings. Different strategies must be compared in order to select the optimal solution in terms of structural safety, costs and architectural, functional and management requirements.

As for the final design solution, the structural intervention must comprise at least: 
- Modification of the structural system to obtain a more favorable dynamic behavior;

- Addition of new structural elements;

- Strengthening of some structural elements to sustain seismic actions through steel jacketing and bracing system for the seismic protection of RC structures;

- Efficient and quick strengthening of RC slabs for gravity loads, for example, based on external unbounded post-tensioning;

- Elimination of degradation and deterioration effects (mainly due to corrosion).

For the final retrofit strategies, the structural intervention is mainly conditioned by the functional and management requirements and the subsequent minimization of the impact on the daily use of the buildings. Based on the preservation requirements, the global demolition and replacement with similar architectural characteristics should not be considered. On the contrary, the final retrofit configuration should be mainly carried out based on reversible and external techniques.

Finally, it should be noted that an estimate (even if approximate) of costs and amounts for typical interventions is an extremely difficult task. First, for historical RC structures, it seems hard work to identify the typical interventions. In fact, from a typological point of view, they are generally very heterogeneous; on the one hand, this heterogeneity represents an element of interest and often this is the artistic or historical values. On the other hand, and for this reason, each RC construction is generally a single case.

\section{Conclusions}

Meeting the performance upgrade and conservation needs of historical buildings and civil engineering works (for those built in the twentieth century) is a complex activity, which requires the search for a strong balance between conservation, retrofit interventions and essential safety requirements. Moreover, the functional and management requirements and the minimization of the impact on the daily use of the buildings generally plays a key role.

The main concepts must be based on the awareness of the need for retrofit. It cannot entail a simple application of codified rules (as occurs for new works). The knowledge of the characteristics of the buildings and civil engineering works must guide the choices, with quantitative assessments and tools to support a deeper awareness.

In contrast, preservation without any precise consideration of safety is not possible. Very often, the original structural configuration must be modified in order to satisfy the safety requirements and avoid disastrous events and casualties, but also (and mainly from a historical point of view) to avoid failure in seismic events and live loading.

Lastly, the management and intervention strategies of reinforced concrete buildings and civil engineering works of historical interest must include the achievement of the performance levels envisaged by new buildings and the evaluation of the convenience to retrofit.

For subsequent research activities, the engineering methods, procedures, and codes for safety, whichensure the need for protection and preservation of the historical heritage, must be standardized and consistent.

Future research directions should consider that the current classification of historic buildings for RC constructions is not yet exhaustive. The significance and attribution of historical values and cultural heritage needs to be defined. Consequently, the criteria for the recognition and protection of historical values will be defined for RC constructions. In any case, future recommendations must consider that no "balancing act" or "trade-off" is possible for structural safety. Consequently, a rigid approach to the protection of cultural heritage must be avoidedand a highly multidisciplinary approach must be defined.

Finally, it is to be highlighted that currently an estimation of costs for interventions is an extremely difficult task. Considering the importance of the topic, specific strategies should be developed at central governmental level. In recent years, a specific retrofitting strategy for existing private buildings stock has been defined by a law [70]. Nevertheless, the historical RC constructions (buildings and engineering works) are generally public or have a public function. Consequently, specific retrofitting strategies cannot be defined 
using an incentive in terms of tax deduction. Moreover, first of all, the stock of RC buildings and engineering works of historical interest should be defined. The expected performance should be defined and assessed on the basis of a special risk index.

Author Contributions: Conceptualization, M.V., B.M.; methodology, M.V., B.M.; formal analysis, M.V.; investigation, M.V., B.M.; data curation, M.V.; writing-original draft preparation, M.V.; writing-review and editing, M.V., B.M.; visualization, M.V., B.M.; supervision, M.V., B.M.; project administration, M.V.; funding acquisition, M.V. All authors have read and agreed to the published version of the manuscript.

Funding: This research was partially funded by 2020 MIUR PON R\&I 2014-2020 Program (project MITIGO, ARS01_00964).

Institutional Review Board Statement: Not applicable.

Informed Consent Statement: Not applicable.

Data Availability Statement: Not applicable.

Conflicts of Interest: The authors declare no conflict of interest.

\section{References}

1. Dolce, M.; Di Bucci, D. Comparing recent Italian earthquakes. Bull. Earthq. Eng. 2015, 15, 497-533. [CrossRef]

2. Di Ludovico, M.; Prota, A.; Moroni, C.; Manfredi, G.; Dolce, M. Reconstruction process of damaged residential buildings outside historical centres after the L'Aquila earthquake: Part II-Heavy damage reconstruction. Bull. Earthq. Eng. 2017, 15, 693-729. [CrossRef]

3. Vona, M.; Harabaglia, P.; Murgante, B. Thinking about resilience cities studying Italian earthquake. Urban Des. Plan. 2016, 169, 185-199.

4. Fiorento, G.; Forte, A.; Pagano, E.; Sabetta, F.; Baggio, C.; Lavorato, D.; Nuti, C.; Santini, S. Damage patterns in the town of Amatrice after August 24th 2016 Central Italy earthquakes. Bull. Earthq. Eng. 2018, 16, 1399-1423.

5. CEN. European Standard EN 1998-3-2005; Eurocode 8: Design of Structures for Earthquake Resistance-Part 3: Assessment and Retrofitting of Buildings. European Committee for Standardization: Brussels, Belgium, 2005.

6. Payá-Zaforteza, I.; Garlock, M. Eminent Structural Engineer: David, P. Billington (1927-2018). Inspiring Generations Through the Integration of Engineering and Art. Struct. Eng. Int. 2018, 29, 1-4. [CrossRef]

7. Fernández-Ordóñez, D. Eugène Freyssinet: "I Was Born a Builder". Tagungsband. In 28. Dresdner Brückenbau Symposium; Institutfür Massivbau Freunde des Bauingenieurwesense. e.V. TUDIAS: Dresdner, 2018; pp. 101-129. ISSN 1613-1169, ISBN 978-3-86780-544-5.

8. Espion, B. Thin concrete shells by Eugène Freyssinet. In Building Knowledge, Constructing Histories, Proceedings of the 6th International Congress on Construction History (6ICCH 2018), Brussels, Belgium, 9-13 July 2018; CRC Press: Boca Raton, FL, USA, 2018; pp. 199-206, ISBN13: 978-1-138-58414-3. [CrossRef]

9. Bruun, E.P.G. Robert Maillart: The evolution of RC bridge forms. In Proceedings of the 9th International Conference on Short and Medium Span Bridges, Calgary, AB, Canada, 15-18 July 2014.

10. Macchi, G.; Macchi, S.; Jamiolkowski, M.; Pastore, V.; Vanni, D. Strengthening of the San Marco Bell Tower Foundation in Venice, Geotechnics and Heritage; Bilotta, E., Flora, A., Lirer, S., Viggiani, C., Eds.; Taylor \& Francis Group: London, UK, 2013; ISBN 978-1-138-00054-4.

11. Royal Decree n. 2229. Design Code of Reinforced Concrete Structures. 1939. (In Italian)

12. Iori, T. L'ingegneria italiana del dopoguerra: Appunti per una storia. In Teoria e Saperi del Costruire: Saperi, Strumenti, Modelli; Mochi, G., Ed.; ITA-EdizioniModerna: Bologna, Italy, 2005; pp. 763-772.

13. Iori, T. Engineers in Italian architecture. The role of RC in the first half of the twentieth century. In Proceedings of the Second International Congress on Construction History, Queens' College, Cambridge University, Cambridge, UK, 29 March-2 April 2006; EXETER; Short Run Press Exeter: UK, 2006; Volume 2, pp. 1981-1995.

14. Iori, T. Il boom dell'ingegneria italiana: Il ruolo di Gustavo Colonnetti e Arturo Danusso. In Storia dell'ingegneria, atti del $2^{\circ}$ Convegno Nazionale; D’Agostino, S., Ed.; ITA-Cuzzolineditore: Napoli, Italy, 2008; pp. 1501-1510.

15. Iori, T.; Poretti, S. Tra scienza e tecnica. Storia della scuola italiana di Ingegneria. L'IndustriaDelleCostr. 2014, 438, 96-107.

16. Iori, T.; Poretti, S. The language of Structures. The Italian school of engineering. In Proceedings of the Fifth International Congress on Construction History, Chicago, IL, USA, 3-7 June 2015; Bowen, B., Leslie, F.T., Ochsendorf, J., Eds.; Construction History Society of America: Chicago, NY, USA, 2015; Volume 2, pp. 347-354.

17. Verderame, G.M.; Manfredi, G.; Frunzio, G. Le proprietà meccaniche dei calcestruzzi impiegati nelle strutture in cemento armato realizzate negli anni '60. X Convegno nazionale "L'Ingegneria Sismica in Italia". Potenza and Matera, 2001. (In Italian)

18. Elfgren, L.; Thun, H.; Ohlsson, U. Concrete strength in old Swedish concrete bridges. Nord. Concr. Res. 2006, 35, 47-60.

19. Marie-Victoire, E.; Cailleux, E.; Texier, V. Carbonation and historical buildings made of concrete. J. De Phys. IV (Proc.) 2006, 136, 305-318. [CrossRef] 
20. Courard, L.; Gillard, A.; Darimont, A.; Bleus, J.M.; Paquet, P. Pathologies of concrete in Saint-Vincent Neo-Byzantine Church and Pauchot reinforced artificial stone. Constr. Build. Mater. 2012, 34, 201-210. [CrossRef]

21. Carsana, M.; Gastaldi, M.; Redaelli, E. A case study on corrosion conditions and guidelines for repair of a reinforced concrete chimney in industrial environment. Struct. Infrastruct. Eng. 2021. [CrossRef]

22. Macdonald, S. Modern matters: Breaking the barriers to conserving modern heritage. In Conservation Perspectives 49. The GCI Newsletter; Getty Conservation Institute: Suite, LA, USA, 2013.

23. Havinga, L.; Colenbrander, B.; Schellen, H. Heritage significance and the identification of attributes to preserve in a sustainable refurbishment. J. Cult. Herit. 2020, 43, 282-293. [CrossRef]

24. Lidelöw, S.; Örn, T.; Luciani, A.; Rizzo, A. Energy-efficiency measures for heritage buildings: A literature review. Sustain. Cities Soc. 2019, 45, 231-242. [CrossRef]

25. Mosoarca, M.; Victor, G. Structural safety of historical buildings made of reinforced concrete, from Banat region-Romania. J. Cult. Herit. 2013, 14, e29-e34. [CrossRef]

26. Sena-Cruz, J.; Ferreira, R.M.; Ramos, L.F.; Fernandes, F.; Miranda, T.; Castro, F. Luiz Bandeira bridge: Assessment of a historical reinforced concrete (RC) bridge. Int. J. Arch. Herit. 2013, 7, 628-652. [CrossRef]

27. Onysyk, J.; Onysyk, J.; Biliszczuk, J.; Prabucki, P.; Sadowski, K.; Toczkiewicz, R. Strengthening the 100-year-old reinforced concrete dome of the Centennial Hall in Wrocław. Struct. Concr. 2014, 15, 30-37.

28. Marcos, J.; San-José, J.T.; Garmendia, L.; Santamaría, A.; Manso, J.M. Central lessons from the historical analysis of 24 reinforcedconcrete structures in northern Spain. J. Cult. Herit. 2016, 20, 649-659. [CrossRef]

29. Arrieta, L.G.; Rodríguez, I.-M.; Arlanzón, N.L.; Blanco, E.B. Damage assessment and conservation strategy for the largest covered market in Europe: The Ribera Market (Bilbao). Int. J. Archit. Herit. 2018, 12, 997-1018. [CrossRef]

30. Sotiriadis, K.; Aspiotis, K.; Mazur, A.; Tolstoy, P.; Badogiannis, E.; Tsivilis, S. Characterization of Old Concrete from a Heritage Structure of Inousses Cluster of Islands. In Proceedings of the International Conference on Protection of Historical Constructions PROHITECH 2021, Athens, Greece, 25-27 October 2021; pp. 80-89.

31. Mitoulis, S.A.; Domaneschi, M.; Cimellaro, G.P.; Casas, J.R. Bridge and transport network resilience-A perspective. Proc. Inst. Civ. Eng. Bridge Eng. 2021. [CrossRef]

32. Carsana, M.; Biondini, F.; Redaelli, E.; Valoti, D.O. On-Site Corrosion Characterization of 50-Year-Old PC Deck Beams. In Proceedings of the 1st Conference of the European Association on Quality Control of Bridges and Structures, Padova, Italy, 29 August-1 September 2021; pp. 954-961.

33. Malomo, D.; Scattarreggia, N.; Orgnoni, A.; Moratti, M.; Calvi, G.M. Numerical Study on the Collapse of the Morandi Bridge. J. Perform. Constr. Facil. 2020, 34, 04020044. [CrossRef]

34. Biondini, F.; Manto, S.; Beltrami, C.; Panseri, L.; Quaranta, L. BRIDGE I 50 research project: Residual structural performance of a 50-year-old bridge Bridge Maintenance, Safety, Management, Life-Cycle Sustainability and Innovations. In Proceedings of the 10th International Conference on Bridge Maintenaince, Safety and Management, IABMAS, Sapporo, Japan, 28 June-2 July 2021 ; pp. 3337-3344.

35. Cimellaro, G.P.; Arcidiacono, V.; Reinhorn, A.M. Disaster Resilience Assessment of Building and Transportation System. J. Earthq. Eng. 2021, 25, 703-729. [CrossRef]

36. Morgese, M.; Ansari, F.; Domaneschi, M.; Cimellaro, G.P. Post-collapse analysis of Morandi'sPolcevera viaduct in Genoa Italy. J. Civ. Struct. Health Monit. 2020, 10, 69-85. [CrossRef]

37. Santarsiero, G.; Masi, A.; Picciano, V. Durability of Gerber saddles in RC bridges: Analyses and applications (Musmeci Bridge, Italy). Infrastructures 2021, 6, 1-23. [CrossRef]

38. Vona, M.; Anelli, A.; Mastroberti, M.; Murgante, B.; Santa-Cruz, S. Prioritization strategies to reduce the seismic risk of the public and strategic buildings. Disaster Adv. 2017, 10, 1-15.

39. Santa-Cruz, S.; Palomino, J.; Liguori, N.; Vona, M.; Tamayo, R. Seismic Risk Assessment of Hospitals in Lima City Using GIS Tools. In Computational Science and Its Applications-ICCSA 2017; Springer: Cham, Switherlands, 2017; Volume 10406, pp. 354-367.

40. Anelli, A.; Santa-Cruz, S.; Vona, M.; Tarque, N.; Laterza, M. A proactive and resilient seismic risk mitigation strategy for existing school buildings. Struct. Infrastruct. Eng. 2018, 15, 137-151. [CrossRef]

41. Decreto Legislativo 22 Gennaio 2004, n. 42. Codice dei Beni Culturali e del Paesaggio, ai Sensi Dell'articolo 10 Della Legge 6 Luglio 2002, n. 137. G.U. n. 45 del 24 Febbraio 2004, s.o. n. 28 (In Italian). Available online: https:/ / www.bosettiegatti.eu/info/ norme/statali/2004_0042.htm (accessed on 20 February 2022).

42. Ribera, F.; Nesticò, A.; Cucco, P.; Maselli, G. A multicriteria approach to identify the Highest and Best Use for historical buildings. J. Cult. Herit. 2020, 41, 166-177. [CrossRef]

43. Anelli, A.; Vona, M.; Santa-Cruz, S. Comparison of different intervention options for massive seismic upgrading of essential facilities. Buildings 2020, 10, 125. [CrossRef]

44. Vona, M.; Flora, A.; Carlucci, E.; Foscolo, E. Seismic retrofitting resilience-based for strategic RC buildings. Buildings 2021, 11, 111. [CrossRef]

45. Masi, A.; Vona, M. Estimation of the In-Situ Concrete Strength: Provisions of the European and Italian Seismic Codes and Possible Improvements. In Proceedings of the Final Conference of ReLUIS-DPC 2005-2008 Project, Napoli, Italy, 1-3 April 2009.

46. Vona, M.; Nigro, D. Evaluation of the predictive ability of the in situ concrete strength through core drilling and its effects on the capacity of the RC columns. Mater. Struct. Mater. Constr. 2015, 48, 1043-1059. [CrossRef] 
47. Masi, A.; Chiauzzi, L. An experimental study on the within-member variability of in situ concrete strength in RC building structures. Constr. Build. Mater. 2013, 47, 951-961. [CrossRef]

48. Hellebois, A.; Launoy, A.; Pierre, C.; De Lanève, M.; Espion, B. 100-year-old Hennebique concrete, from composition to performance. Constr. Build. Mater. 2013, 44, 149-160. [CrossRef]

49. Vona, M. A review of experimental results about in situ concrete strength. Adv. Mater. Res. 2013, 773, 278-282. [CrossRef]

50. De Stefano, M.; Tanganelli, M.; Viti, S. Variability in concrete mechanical properties as a source of in-plan irregularity for existing RC framed structures. Eng. Struct. 2014, 59, 161-172. [CrossRef]

51. Quagliarini, E.; Clementi, F.; Maracchini, G.; Monni, F. Experimental assessment of concrete compressive strength in old existing RC buildings: A possible way to reduce the dispersion of DT results. J. Build. Eng. 2016, 8, 162-171. [CrossRef]

52. Bertolini, L.; Carsana, M.; Redaelli, E. Conservation of historical reinforced concrete structures damaged by carbonation induced corrosion by means of electrochemical realkalisation. J. Cult. Herit. 2008, 9, 376-385. [CrossRef]

53. Bertolini, L.; Carsana, M.; Gastaldi, M.; Lollini, F.; Redaelli, E. Corrosion assessment and restoration strategies of reinforced concrete buildings of the cultural heritage. Mater. Corros. 2011, 62, 146-154. [CrossRef]

54. Coronelli, D.; Gambarova, P.G. Structural Assessment of Corroded Reinforced Concrete Beams: Modeling Guidelines. ASCE J. Struct. Eng. 2004, 130, 1214-1224. [CrossRef]

55. Cairns, J.; Plizzari, G.A.; Du, Y.; Law, D.W.; Franzoni, C. Mechanical properties of corrosion-damaged reinforcement. ACI Mater. J. 2005, 102, 256-264.

56. Broomfield, J.P. Corrosion of Steel in Concrete: Understanding, Investigation and Repair, 2nd ed.; Taylor \& Francis Ltd.: London, UK, 2006; ISBN13: 978-0415334044.

57. Rinaldi, Z.; Valente, C.; Pardi, L. A simplified methodology for the evaluation of the residual life of corroded elements. Struct. Infrastruct. Eng. 2008, 4, 139-152. [CrossRef]

58. Prieto, M.; Tanner, P.; Andrade, C. Bond Response in Structural Concrete with Corroded Steel Bars. Experimental Results, Modelling of Corroding Concrete Structures. In Proceedings of the Joint Fib-RILEM Workshop; RILEM Bookseries; Madrid, Spain, 22-23 November 2010, 2011; Volume 5, pp. 231-241.

59. Ou, Y.; Tsai, L.; Chen, H. Cyclic performance of large-scale corroded reinforced concrete beams. Earthq. Eng. Struct. Dyn. 2012, 41, 593-604. [CrossRef]

60. Cardone, D.; Perrone, G.; Sofia, S. Experimental and numerical studies on thecyclic behavior of R/C hollow bridge piers with corroded rebars. Earthq. Struct. 2013, 4, 41-62. [CrossRef]

61. Yiu, C.Y. Building depreciation and sustainable development. J. Build. Apprais. 2007, 3, 97-103. [CrossRef]

62. Manganelli, B. Maintenance, building depreciation and land rent. Appl. Mech. Mater. 2013, 357-360, 2207-2214. [CrossRef]

63. Yasin, M.N.; Rosli, M.Z.R.; Hamid, M.; Zakaria, M.A.; Deraman, R. Deferred maintenance of buildings: A review paper. In Proceedings of the 10th Asia Pacific Structural Engineering and Construction Conference, Langkawi, Malaysia, 13-15 November 2018.

64. Knight, J.R.; Sirmans, C.F. Depreciation, Maintenance, and Housing Prices. J. Hous. Econ. 1996, 5, 369-389. [CrossRef]

65. Manganelli, B.; Vona, M.; De Paola, P. Evaluating the cost and benefits of earthquake protection of buildings. J. Eur. Real Estate Res. 2018, 11, 263-278. [CrossRef]

66. Giaccone, D.; Fanelli, P.; Santamaria, U. Influence of the geometric model on the structural analysis of architectural heritage J. Cult. Herit. 2020, 43, 144-152. [CrossRef]

67. Vona, M.; Cascini, G.; Mastroberti, M.; Murgante, B.; Nolè, G. Characterization of URM buildings and evaluation of damages in a historical center for the seismic risk mitigation and emergency management. Int. J. Disaster Risk Reduct. 2017, 24, 251-263. [CrossRef]

68. Toni, E.; Cello, G. Spatiotemporal evolution of the Central Apennines fault system (Italy). J. Geodyn. 2003, 36, 113-128. [CrossRef]

69. Mulargia, F.; Stark, P.B.; Robert, J.; Geller, R.J. Why is Probabilistic Seismic Hazard Analysis (PSHA) still used? Phys. Earth Planet. Inter. 2017, 264, 63-75. [CrossRef]

70. Ministerial Decree 58/2017. Sisma Bonus_Linee Guida per la Classificazione del Rischio Sismico delle Costruzioni Nonché le Modalità per L'attestazione, da Parte di Professionisti Abilitati, Dell'efficacia Degli Interventi Effettuati; Ministero delle Infrastrutture e dei Trasporti: Rome, Italy, 2017. (In Italian) 